\title{
Effect of Amylomaize Starch on Plasma Lipoproteins of Lean and Obese Zucker Rats
}

\author{
Denis Mathe,, ${ }^{1, *}$ Michel Riottot, ${ }^{2}$ Najmuddin Rostaqui, ${ }^{1}$ \\ Edmond SACQuet, ${ }^{3}$ Nicole NAVArRo, ${ }^{1}$ \\ Bernard LÉCUYER, ${ }^{1}$ and Claude LUTTON ${ }^{2}$ \\ ${ }^{1}$ Unité de Recherches sur les Dyslipidémies et l'Athérosclérose, INSERM \\ U 32, Hôpital Henri-Mondor, 94010 Créteil, France \\ ${ }^{2}$ Laboratoire de Physiologie de la Nutrition, UA 646 CNRS, \\ Université Paris-Sud, 91400 Orsay, France \\ ${ }^{3}$ Laboratoire des Animaux sans Germes, CNRS-INRA, \\ 78350 Jouy-en Josas, France
}

(Received May 30, 1992)

\begin{abstract}
Summary Male Zucker rats either genetically obese $(\mathrm{fa} / \mathrm{fa})$ or lean $(\mathrm{Fa} /-)$ were fed a semi-purified diet containing either cornstarch or amylomaize starch (Eurylon $7 \mathrm{R}$ ) rich in amylose (70\%). Obese rats were hyperlipidemic (cholesterol, $3.27 \pm 0.18$; triglycerides, $2.11 \pm 0.12 \mathrm{~g} /$ liter), when compared with lean rats (cholesterol, $1.13 \pm 0.03$; triglycerides, $0.75 \pm 0.05 \mathrm{~g} /$ liter). The amylomaize diet did not reduce the body weight of the Zucker rats. However, it decreased weight, esterified cholesterol, and triglyceride content of the liver in both lean and obese rats. The amylomaize diet decreased plasma cholesterol levels of obese rats $(-42 \%)$ and lean rats $(-30 \%)$, while plasma triglyceride levels were significantly decreased only in the lean rats $(-43 \%)$. The cholesterol content of chylomicrons, VLDL, $\mathrm{LDL}_{1}$ (1.006-1.040), and $\mathrm{LDL}_{2}$ (1.040-1.063, which contains apo E-rich HDL) was reduced by 40 to $50 \%$, while that of HDL was reduced by only $20 \%$ (lean) or $23 \%$ (obese). Diet containing amylose-rich starch therefore constitutes a promising new way of nutritional control of hyperlipidemias.
\end{abstract}

Key Words: lipoproteins, Zucker rat, starch, cholesterol, triglycerides

Nutritional factors that can decrease plasma cholesterol levels and consequently reduce the risk of atherosclerosis, such as lipids [1,2], fibers [3], and plant proteins [4], have been intensively studied. However, much less information is

* To whom correspondence should be addressed. 
available concerning the effects of the quality of starch on plasma lipid levels.

Hypocholesterolemic effects of starch feeding have been previously observed in rats and rabbits fed potato starch [5]. Recently it was reported that a diet containing an amylomaize starch decreased plasma cholesterol levels by about $40 \%$ in conventional or in germ-free rats [6]. However, this study did not examine the precise effects of this starch on the different plasma lipoproteins. This starch (trade name Eurylon $7 \mathrm{R}$ ) is characterized by a high proportion of amylose, whereas normal cornstarch is poor in amylose and rich in amylopectin. In this study the effects of this starch on plasma lipid levels and on lipoprotein composition was examined in lean and obese Zucker rats. The obese Zucker rats are characterized by a genetic defect that results in marked hypertriglyceridemia and moderate hypercholesterolemia [7]. They have an overproduction of triacylglycerol-rich very low density lipoproteins (VLDL) by the liver [8], and can be considered as a model of type IV human dyslipidemia. These rats provide an opportunity to demonstrate the efficacy of amylose-rich starch in the dietary treatment of genetic hyperlipidemia.

\section{MATERIALS AND METHODS}

Animals and diet. Two-month-old male Zucker rats (CSEAL, Orléans, France) either genetically obese $(\mathrm{fa} / \mathrm{fa} ; \mathrm{OB})$ or lean $(\mathrm{Fa} /-; \mathrm{C})$ were kept separately in an air-conditioned animal house with a light period from 8 a.m. to 8 p.m. They were fed ad libitum for a period of 2 months a semi-purified diet containing cornstarch (diet S) or amylomaize starch (diet E). The amylomaize starch, containing 70\% (w/w) amylose, was registered under the name of "Eurylon 7R" (Roquette Frères, Lestrem, France). The semi-purified diet was composed of 53\% starch, 23\% casein, 9.2\% lard, $0.8 \%$ walnut oil, $4 \%$ skimmed milk, $5 \%$ salt mixture, $2.5 \%$ agar-agar, with vitamins and $2.3 \%$ yeast [9]. The cholesterol content of the diet was $0.015 \%$.

The animals were killed by intra-aortic puncture at 1 p.m. under pentobarbital anesthesia. Blood from each rat was collected in syringes containing $0.3 \mathrm{ml}$ of NaEDTA (4\%), monoiodoacetamide (4\%), and $\mathrm{NaN}_{3}(0.2 \%)$. The liver was removed after washing of the cardiovascular system with isotonic saline.

Lipoprotein separation. Plasma was separated from blood cells by centrifugation at $2,200 \times g$ for $15 \mathrm{~min}$ at $4^{\circ} \mathrm{C}$. Lipoprotein fractions were obtained by flotation after sequential ultracentrifugation in solution of densities $1.006 \mathrm{~g} / \mathrm{ml}$ (chylomicrons + VLDL), $1.040 \mathrm{~g} / \mathrm{ml}\left(\mathrm{LDL}_{1}\right)$, and $1.063 \mathrm{~g} / \mathrm{ml}\left(\mathrm{LDL}_{2}\right)$ for $24 \mathrm{~h}$ at $40,000 \mathrm{rpm}$ in a $50 \mathrm{Ti}$ Beckman rotor in an L8 Beckman centrifuge $\left(10^{8} \times g \times \mathrm{min}\right)$ according to references [10] and [11]. HDL cholesterol was determined directly after removal of the $d<1.063 \mathrm{~g} / \mathrm{ml}$ floating lipoproteins $\left(10^{8} \times g \times \min \right)$ in the subnatent fraction. For further chemical analysis (triacylglycerol, phospholipid, and protein contents), HDL was isolated by additional centrifugation in $1.21 \mathrm{~g} / \mathrm{ml}$ solution $\left(2 \times 10^{8} \times g \times \mathrm{min}\right)$. 
Chemical analysis. Proteins were assayed by the method described by Lowry et al. [12], using bovine serum albumin as the standard. Samples were extracted with chloroform after color development in order to avoid turbidity due to lipids. Lipids in plasma and lipoproteins were determined by use of commercial kits employing enzymatic methods: total and free cholesterol from Boehringer (Mannheim, Germany), triacylglycerol and phospholipids from Wako, Biolyon (Paris, France). Core/surface ratio of lipoproteins was calculated from triacylglycerol+ cholesteryl ester masses (core) and free cholesterol+phospholipids + protein masses (surface). Cholesteryl ester mass was calculated from the cholesterol amount esterified $\times 1.7$.

Methods for extraction and analysis of cholesterol in liver were as previously described [9]. Liver triacylglycerol was measured after lipid extraction by the Folch procedure [13]. Phospholipids were first removed by adsorption on silicic acid. Enzymatic determination of glycerol (kit Boehringer GmBH, Mannheim, Germany) was then performed after saponification in ethanolic $\mathrm{KOH}(0.5 \mathrm{~N})$ and neutralization of the mixture.

Results were expressed as mean \pm standard error of the mean, and statistical differences were determined by either multivariant analysis ANOVA, with Newmann Keuls test or Student's $t$-test.

\section{RESULTS}

Body weight, which was much higher in obese than in lean rats, was not affected by the amylomaize diet (Table 1). Food intake was slightly higher for obese rats $(18.2 \pm 1.4 \mathrm{~g} /$ day $)$ than for lean rats $(16.4 \pm 1.8 \mathrm{~g} /$ day $)$ when the animals

Table 1. Body weight, liver weight, cholesterol and triglyceride concentrations in liver and plasma of lean (C) or obese (OB) Zucker rats fed cornstarch (S) or amylomaize (E) diet.

\begin{tabular}{lcccc}
\hline & \multicolumn{4}{c}{ Experimental groups } \\
\cline { 2 - 5 } & S-C & S-OB & E-C & E-OB \\
\hline Number of animals & 5 & 6 & 5 & 6 \\
Body weight (g) & $399 \pm 6$ & $538 \pm 10^{\mathrm{b}}$ & $356 \pm 12$ & $550 \pm 12$ \\
Liver weight (g) & $14.3 \pm 0.3$ & $29.7 \pm 1.6^{\mathrm{b}}$ & $12.0 \pm 0.8^{\mathrm{c}}$ & $22.1 \pm 0.8^{\mathrm{b}, \mathrm{e}}$ \\
\hline Liver lipids (mg/g) & & & \\
Free cholesterol & $1.92 \pm 0.07$ & $1.64 \pm 0.08$ & $1.85 \pm 0.09$ & $1.70 \pm 0.04$ \\
Cholesteryl esters & $1.23 \pm 0.09$ & $1.37 \pm 0.18$ & $0.34 \pm 0.01^{\mathrm{e}}$ & $0.90 \pm 0.11^{\mathrm{a}, \mathrm{d}}$ \\
Triglycerides & $9.3 \pm 1.0$ & $77.8 \pm 6.2^{\mathrm{c}}$ & $6.3 \pm 0.6^{\mathrm{a}}$ & $62.3 \pm 5.6$ \\
\hline Plasma lipids (g/liter) & & & & \\
Total cholesterol & $1.13 \pm 0.03$ & $3.27 \pm 0.18^{\mathrm{b}}$ & $0.79 \pm 0.05^{\mathrm{e}}$ & $1.90 \pm 0.13^{\mathrm{b}, \mathrm{e}}$ \\
Free cholesterol & $0.32 \pm 0.02$ & $0.78 \pm 0.09^{\mathrm{b}}$ & $0.20 \pm 0.03^{\mathrm{e}}$ & $0.45 \pm 0.06^{\mathrm{b}, \mathrm{e}}$ \\
Triglycerides & $0.75 \pm 0.05$ & $2.11 \pm 0.12^{\mathrm{b}}$ & $0.43 \pm 0.04^{\mathrm{e}}$ & $1.74 \pm 0.15^{\mathrm{b}}$ \\
\hline
\end{tabular}

Results are expressed as mean \pm SEM. Significantly different at: ${ }^{\mathrm{a}} p<0.05 ;{ }^{\mathrm{b}} p<0.001$ for $\mathrm{OB}$ vs. $\mathrm{C}$ rats and ${ }^{\mathrm{c}} p<0.05 ;{ }^{\mathrm{d}} p<0.01 ;{ }^{\mathrm{e}} p<0.001$ for $\mathrm{E}$ vs. $\mathrm{S}$ diets. 
Table 2. Composition of plasma lipoproteins from lean (C) Zucker rats fed either cornstarch (S) or amylomaize starch (E).

\begin{tabular}{|c|c|c|c|c|c|c|}
\hline & \multicolumn{3}{|c|}{ Cholesterol } & \multirow{2}{*}{$\begin{array}{l}\text { Trigly- } \\
\text { cerides }\end{array}$} & \multirow{2}{*}{$\begin{array}{l}\text { Phospho- } \\
\text { lipids }\end{array}$} & \multirow{2}{*}{ Proteins } \\
\hline & Group & Total & Free & & & \\
\hline \multirow{2}{*}{$\begin{array}{l}\text { Chylomicrons + VLDL } \\
(d<1.006 \mathrm{~g} / \mathrm{ml})\end{array}$} & S-C & $74 \pm 9$ & $63 \pm 5$ & $632 \pm 42$ & $116 \pm 13$ & $110 \pm 15$ \\
\hline & E-C & $36 \pm 4^{b}$ & $21 \pm 5^{b}$ & $314 \pm 47^{c}$ & $47 \pm 1^{b}$ & $62 \pm 4^{a}$ \\
\hline \multirow{2}{*}{$\begin{array}{l}\mathrm{LDL}_{1} \\
(1.006<d<1.040 \mathrm{~g} / \mathrm{ml})\end{array}$} & S-C & $75 \pm 6$ & $24 \pm 2$ & $55 \pm 4$ & $59 \pm 6$ & $77 \pm 8$ \\
\hline & E-C & $49 \pm 11^{\mathrm{a}}$ & $17 \pm 1$ & $33 \pm 2^{c}$ & $31 \pm 2^{\mathrm{b}}$ & $55 \pm 1^{\mathrm{a}}$ \\
\hline \multirow{2}{*}{$\begin{array}{l}\mathrm{LDL}_{2} \\
(1.040<d<1.063 \mathrm{~g} / \mathrm{ml})\end{array}$} & S-C & $226 \pm 12$ & $68 \pm 6$ & $28 \pm 2$ & $207 \pm 12$ & $164 \pm 11$ \\
\hline & E-C & $139 \pm 9^{c}$ & $36 \pm 2^{c}$ & $32 \pm 1$ & $133 \pm 7^{\mathrm{b}}$ & $115 \pm 7^{b}$ \\
\hline \multirow{2}{*}{$\begin{array}{l}\mathrm{HDL} \\
(1.063<d<1.210 \mathrm{~g} / \mathrm{ml})\end{array}$} & S-C & $686 \pm 50$ & $152 \pm 7$ & $45 \pm 8$ & $812 \pm 23$ & $1,062 \pm 18$ \\
\hline & E-C & $550 \pm 12^{\mathrm{a}}$ & $124 \pm 10^{\mathrm{b}}$ & $49 \pm 4$ & $659 \pm 38^{b}$ & $806 \pm 7^{c}$ \\
\hline
\end{tabular}

Results are expressed as mean \pm SEM $(n=4)(\mathrm{mg} /$ liter plasma). Significantly different at: ${ }^{\text {a }} p<0.05$; ${ }^{\text {b }} p<0.01 ;{ }^{\text {c }} p<0.001$.

Table 3. Composition of plasma lipoproteins from obese (OB) Zucker rats fed either cornstarch (S) or amylomaize starch (E).

\begin{tabular}{lcccccc}
\hline & \multicolumn{3}{c}{ Cholesterol } & Trigly- & $\begin{array}{c}\text { Phospho- } \\
\text { cerides } \\
\text { lipids }\end{array}$ & Proteins \\
\cline { 2 - 4 } & Group & Total & Free & & \\
\hline Chylomicrons +VLDL & S-OB & $115 \pm 10$ & $78 \pm 8$ & $1,927 \pm 129$ & $309 \pm 16$ & $202 \pm 24$ \\
$(d<1.006 \mathrm{~g} / \mathrm{ml})$ & E-OB & $71 \pm 6^{\mathrm{b}}$ & $59 \pm 9$ & $1,585 \pm 144^{\mathrm{c}}$ & $265 \pm 33$ & $143 \pm 20$ \\
\hline $\mathrm{LDL}_{1}$ & S-OB & $130 \pm 11$ & $24 \pm 3$ & $69 \pm 4$ & $101 \pm 11$ & $175 \pm 19$ \\
$(1.006<d<1.040 \mathrm{~g} / \mathrm{ml})$ & E-OB & $60 \pm 5^{\mathrm{b}}$ & $14 \pm 2^{\mathrm{a}}$ & $66 \pm 1$ & $53 \pm 5^{\mathrm{b}}$ & $127 \pm 17^{\mathrm{a}}$ \\
\hline $\mathrm{LDL}_{2}$ & S-OB & $750 \pm 7$ & $155 \pm 14$ & $65 \pm 4$ & $724 \pm 27$ & $631 \pm 24$ \\
$(1.040<d<1.063 \mathrm{~g} / \mathrm{ml})$ & E-OB & $373 \pm 30^{\mathrm{c}}$ & $66 \pm 4^{\mathrm{c}}$ & $61 \pm 3$ & $307 \pm 28^{\mathrm{c}}$ & $351 \pm 21^{\mathrm{c}}$ \\
\hline $\mathrm{HDL}$ & S-OB & $1,440 \pm 32$ & $323 \pm 11$ & $51 \pm 6$ & $2,205 \pm 93$ & $2,552 \pm 64$ \\
$(1.063<d<1.210 \mathrm{~g} / \mathrm{ml})$ & E-OB & $1,11 \pm 46^{\mathrm{b}}$ & $247 \pm 5^{\mathrm{c}}$ & $27 \pm 1^{\mathrm{b}}$ & $1,663 \pm 40^{\mathrm{b}}$ & $2,142 \pm 77^{\mathrm{b}}$ \\
\hline
\end{tabular}

Results are expressed as mean \pm SEM $(n=4)(\mathrm{mg} /$ liter plasma). Significantly different at: ${ }^{\mathrm{a}} p<0.05 ;{ }^{\mathrm{b}} p<0.01 ;{ }^{\mathrm{c}} p<0.001$.

were fed the cornstarch diet. Dietary intake was increased moderately in both groups when they were given the amylomaize diet $(20.1 \pm 2.2 \mathrm{~g} /$ day and $18.2 \pm 1.4$ $\mathrm{g} /$ day for obese and lean rats, respectively).

Obese rats had a larger liver than lean rats, representing $5.54 \pm 0.36 \%(\mathrm{OB})$ vs. $3.58 \pm 0.40 \%$ (C) of body weight $(p<0.01)$, when fed the cornstarch diet. The amylomaize diet significantly decreased liver weight in both lean $(-16 \%)$ and obese $(-25 \%)$ rats (Table 1). The concentrations of free cholesterol in the liver were identical in all experimental groups, while the ingestion of the amylomaize diet decreased the liver concentration of cholesteryl esters in both lean $(-72.4 \%)$ and obese $(-34.3 \%)$ rats. Consequently, total liver cholesterol was decreased from $45.2 \pm 3.2 \mathrm{mg}$ for lean rats fed the cornstarch diet ( $\mathrm{S}-\mathrm{C}$ group) to $26.1 \pm 8.7 \mathrm{mg}$ (E-C group) ( $p<0.001)$, while in obese rats this content was reduced from $89.4 \pm 8.0 \mathrm{mg}$ to $57.6 \pm 4.6 \mathrm{mg}(p<0.01)$.

Plasma cholesterol concentrations were decreased in both lean rats $(-30.1 \%)$ 
and obese rats $(-41.9 \%)$ fed the amylomaize diet, while plasma triglyceride levels were significantly decreased only in lean rats $(-42.7 \%)$. The concentrations of lipids and proteins in plasma lipoproteins are presented in Table 2 for lean rats and in Table 3 for obese rats. Higher cholesterol levels were found in all lipoproteins of obese rats fed the cornstarch diet, but the increase was more pronounced in $\mathrm{LDL}_{2}$ (3.3 fold) and HDL (2.1 fold). The amylomaize diet significantly decreased the cholesterol concentration in chylomicrons + VLDL, $\mathrm{LDL}_{1}$ and $\mathrm{LDL}_{2}(-40$ to $50 \%)$ of lean and obese rats, while the decrease in cholesterol concentration was less marked in HDL ( $-20 \%$ in lean and $-23 \%$ in obese rats). Consequently the proportion of plasma cholesterol transported by HDL increased in both lean and obese rats fed the amylomaize diet. Plasma triglycerides were mainly present in the $d<1.006 \mathrm{~g} / \mathrm{ml}$ lipoprotein fraction. The amylomaize diet significantly decreased the triglyceride concentration in this fraction $(-50 \%)$ in lean rats but only by $18 \%$ in obese rats. The effects of this diet on the phospholipids and protein concentrations of various lipoproteins were comparable to those observed for cholesterol. Therefore the relative proportions of lipids and proteins within each lipoprotein fraction were not significantly modified by the amylomaize diet.

\section{DISCUSSION}

The characteristics of the cholesterol system of lean and obese Zucker rats have been previously reported $[14,15]$. The animals were fed a semi-purified diet similar to that of the present study except that sucrose was used in place of starch. Feeding the animals with cornstarch or with Eurylon (high-amylose starch) did not prevent the development of obesity. When the animals were fed the sucroserich diet, the triglyceride concentration in the liver was very high (22.3 and 88.9 $\mathrm{mg} / \mathrm{g}$ for lean and obese rats, respectively) [14], in accord with another report [16]. Feeding cornstarch strikingly reduced this concentration in both lean and obese Zucker rats (Table 1). In comparison with the cornstarch one, the amylomaize diet significantly decreased the concentration of liver triglycerides in lean rats but not in obese rats. However, since liver weight was reduced by this diet, the total triglyceride content of liver was reduced by $43.2 \%$ in lean rats and by $40.4 \%$ in obese rats, when cornstarch was replaced by amylomaize. When compared with the amylopectin-rich starch (corn), the amylose-rich starch (amylomaize) decreased plasma cholesterol levels in both lean and obese rats. In addition, liver cholesteryl ester concentrations were also decreased (Table 1). These effects of amylomaize diet in Zucker rats were similar to those previously reported in conventional or germ-free rats of the Fisher strain [6].

As already observed, the Zucker obese rats develop marked hyperlipidemia characterized by an elevation in all lipoproteins, but particularly those in the VLDL fraction $[8,15]$. VLDL were enriched in triglycerides and were larger and less dense. Their separation from chylomicrons was imprecise and we chose, as

Vol. 14, No. 1, 1993 
before [15], to analyze them together as a $d<1.006 \mathrm{~g} / \mathrm{ml}$ fraction named triglyceride-rich lipoproteins (TRL). However, since the animals were killed at 1 p.m., the actual amount of chylomicrons in TRL should be low. The core/surface ratios of this fraction were significantly higher in obese rats $(3.38 \pm 0.28)$ than in lean rats $(2.25 \pm 0.19, p<0.05)$. Triglyceride concentrations of TRL were more markedly reduced by the amylomaize diet in lean $(-50.3 \%)$ than in obese $(-17.8 \%)$ animals. However, the core/surface ratios were not changed by the diet. This diet decreased the cholesterol concentration in all lipoprotein fractions in both lean and obese Zucker rats. However, cholesterol levels were more markedly decreased in the $d<$ $1.063 \mathrm{~g} / \mathrm{ml}$ lipoproteins ( -35 to $-50 \%)$, which contains apo E-rich HDL [17], than in HDL, in which the decrease was only $20 \%$ in lean rats and $23 \%$ in obese rats. Other constituents, phospholipids and protein, were decreased to a similar degree as cholesterol. Consequently, their relative proportions in the various lipoproteins were not modified by the amylomaize diet. This suggests that the decreased concentration of plasma lipids was related to a decreased number of lipoprotein particles circulating in the plasma. The decrease in plasma cholesterol after consumption of an amylomaize diet agrees with the observations of Carroll et al. [5] on potato starch. Similarly, it was observed in rats that cyclodextrins, the digestibility of which in low, decrease both lipoprotein levels and liver synthesis of triglycerides [18]. In man fed $20 \%$ cornstarch rich in amylose, cholesterol and triglyceride contents of VLDL and LDL were reduced as were apo B, apo CII, and apo CIII plasma levels [19].

The mechanism(s) involved in the hypolipidemic effect of amylose-rich starch remains an open question. Among the several biological modifications within the gut reported in rats and hamster fed this starch $[6,20,21]$, the increased biliary secretion of bile acid would agree with an accelerated catabolism of lipoproteins by the liver. Another hypothesis to explain the effects of this starch on plasma lipids concerns its effect on insulin and glucagon levels, since the intestinal hydrolysis of amylose-rich starch and therefore the glucose release are slow. Indeed, glucose and insulin responses were decreased when the amylose content of rice starch [22] and cornstarch [23, 24] was increased. Moreover O'Dea et al. showed that the insulin response after a meal was closely related to the starch digestibility tested in vitro [25]. The glucagon/insulin ratio is quite important in determining the plasma lipid levels. We have previously reported that an increase in this ratio after chronic administration of glucagon reduced plasma lipid and lipoprotein levels [26]. The modification of the hormonal state, insulin and glucagon as well as gut hormone levels, requires further careful analysis to more clearly understand the mechanism of the hypolipemic effect of this starch.

In conclusion, a diet containing amylose-rich starch could constitute an interesting new way of nutritional control of hyperlipidemias. 


\section{REFERENCES}

1. Grundy, S.M., and Denke, M.A. (1990): Dietary influences on serum lipids and lipoproteins. J. Lipid Res., 31, 1149-1172.

2. Harris, W.S. (1989): Fish oils and plasma lipid and lipoprotein metabolism in humans: A critical review. J. Lipid Res., 30, 785-807.

3. MacPherson-Kay, R. (1982): Dietary fiber. J. Lipid Res., 23, 221-242.

4. Forsythe, W.A., Green, M.S., and Anderson, J.J.B. (1989): Dietary protein effects on cholesterol and lipoprotein concentrations: A review. J. Am. Coll. Nutr., 5, 553-549.

5. Carroll, K.K., Hamilton, R.M.G., Huff, M.W., and Falloner, A.D. (1978): Dietary fiber and cholesterol metabolism in rabbits and rats. Am. J. Clin. Nutr., 31, S203-S207.

6. Sacquet, E., Leprince, C., and Riottot, M. (1983): Effect of amylomaize starch on cholesterol and bile acid metabolism in germ-free (axenic) and conventional (holoxenic) rats. Reprod. Nutr. Dev., 23, 783-792.

7. Bray, G.A. (1973): The Zucker fatty rat: A review. Fed. Proc., 36, 148-153.

8. Schonfeld, G., and Pfleger, B. (1971): Overproduction of VLDL by livers of genetically obese rats. Am. J. Physiol., 220, 1178-1181.

9. Mathé, D., Lutton, C., Rautureau, J., Coste, T., Goufier, E., Sulpice, J.C., and Chevallier, F. (1977): Effects of dietary fiber and salt mixtures on the cholesterol metabolism of rats. $J$. Nutr., 107, 466-474.

10. Koga, S., Horowitz, D.L., and Scanu, A.M. (1969): Isolation and properties of lipoproteins from normal rat serum. J. Lipid Res., 5, 577-588.

11. Fidge, N.H., and Poulis, P. (1978): Metabolic heterogeneity in the formation of low density lipoprotein from very low density lipoprotein in the rat: Evidence for the independent production of a low density lipoprotein subfraction. J. Lipid Res., 19, 342-349.

12. Lowry, O.H., Rosebrough, N.J., Farr, A.L., and Randall, L.J. (1951): Protein measurement with the Folin phenol reagent. J. Biol. Chem., 193, 265-275.

13. Folch, J., Less, M., and Stanley, G.M.S. (1957): A simple method for the isolation and purification of total lipids from animal tissues. J. Biol. Chem., 226, 497-509.

14. Bendjellit, S., Mathé, D., Castaing, D., Bismuth, H., and Lutton, C. (1985): Cholesterol metabolism in lean and obese Zucker rats: Effects of portacaval anastomosis. Int. J. Obe., 9, 1-9.

15. Mathé, D., Bendjellit, S., and Castaing, D. (1987): Effect of portacaval anastomosis on plasma lipoproteins of lean and obese Zucker rats. Atherosclerosis, 64, 155-162.

16. Novikoff, P.M. (1977): Fatty liver induced in Zucker fatty (ff) rats by a semi-synthetic diet rich in sucrose. Proc. Natl. Acad. Sci. U.S.A., 74, 3038-3042.

17. Sérougne, C., Mathé, D., and Lutton, C. (1988): Induction of long lasting hypercholesterolemia in the rat fed a cystine-enriched diet. Lipids, 23, 930-936.

18. Suzuki, M., and Sato, A. (1985): Nutritional significance of cyclodextrins: Indigestibility and hypolipemic effect of alpha-cyclodextrin. J. Nutr. Sci. Vitaminol., 31, 209-223.

19. Reiser, S., Powell, A.S., Scholfied, D.J., Paude, P., Ellwod, K.C., and Canary, J.J. (1989): Blood lipids, lipoproteins, apoproteins and uric acid in men fed diets containing fructose or high-amylose cornstarch. Am. J. Clin. Nutr., 49, 832-839.

20. Riottot, M., and Sacquet, E. (1985): Increase in the ileal absorption rats of sodium taurocholate in germ-free or conventional rats given an amylomaize starch diet. Br. J. Nutr., $\mathbf{5 3}$, $307-310$.

21. Khallou, J., Lutton, C., Parquet, M., Riottot, M., and Verneau, C. (1988): Biodynamics of cholesterol and bile acids in cholelithiasic hamster: Effect of amylomaize starch. J. Physiol. (London), 406, 55.

22. Goddard, M.S., Young, G., and Marcus, R. (1984): The effect of amylose content on insulin and glucose responses to ingested rice. Am. J. Clin. Nutr., 39, 388-392.

Vol. 14, No. 1, 1993 
23. Behall, K.M., Scholfied, D.J., and Canary, J.J. (1988): The effect of starch structure on glucose and insulin response in adult subjects. Am. J. Clin. Nutr., 47, 428-432.

24. Behall, K.M., Scholfied, D.J., Yohaniak, I., and Canary, J.J. (1989): Diets containing high amylose vs amylopectin starch: Effects on metabolic variables in human subjects. Am. J. Clin. Nutr., 49, 337-344.

25. O'Dea, K., Snow, P., and Nestel, P. (1981): Rate of starch hydrolysis in vitro as a predictor of metabolic responses to complex carbohydrate in vivo. Am. J. Clin. Nutr., 34, 1991-1993.

26. Guettet, C., Mathé, D., Navarro, N., and Lecuyer, B. (1989): Effects of chronic glucagon administration on rat lipoprotein composition. Biochim. Biophys. Acta, 1005, 233-238. 